\title{
Thinking pattern of first grade students towards edentulous replacement
}

\author{
Eri H. Jubhari \\ Department of Prosthodontics and Dental Materials \\ Faculty of Dentistry Hasanuddin University \\ Makassar - Indonesia
}

\begin{abstract}
Many people ignore their oral hygiene and do not use denture after extraction. This may caused by their thinking pattern. Thinking pattern indicates the degree of comprehension to solve a problem. This research aims to find out the thinking pattern of first year students towards edentulous replacement. The questionnaire was filled in by students. The oral cavity state of students who have edentulous was inspected. The study finds that only 3 men and 27 women had edentulous, all of them did not use denture. However, more than $96 \%$ of the edentulous and not-edentulous groups said that edentulous need denture, due to aesthetic factor. The reasons for not using denture are, for example, not enough time, not disturbed by the absence of denture, and its cost. It can be concluded that the 2005 batch students of Faculty of Dentistry (FKG) UNHAS had shown a good understanding about edentulous replacement. Their views on the profits and detriments using denture are the main reasons to determine whether they will use denture.
\end{abstract}

Key words: thinking pattern, first grade students, edentulous replacement

Correspondence: Eri H. Jubhari, c/o: Bagian Prostodonsia dan Ilmu Material dan Teknologi Kedokteran Gigi, Fakultas Kedokteran Gigi Universitas Hasanuddin. Jl. Kandea No. 5 Makassar, Indonesia. E-mail:erihjubhari@lycos.com

\section{INTRODUCTION}

For many people, dental health is unimportant and sometimes is ignored. This statement, however, is not right at all.

Stoll, ${ }^{1}$ said that teeth are the source of many physical and mental problems. From the early of one's life, teeth can cause pain and inconvenient. First, a baby feels glad when sucked, but the happiness disappears when his teeth erupt. Then, the child looks very fearful when the deciduous is extracted unless his parents explain that it is natural in growing. Basically everyone will feel fear to lose part of their body including teeth.

If people lose one or more of their teeth, they will be unable to chew and speak, and it will influence their aesthetic. McGuire ${ }^{2}$ said that loss of teeth can cause specific problems in brushing teeth especially at the upper or the lower parts of the edentulous and at the empty space due to the extraction. This is caused by the inadequately processed self-cleansing.

The loss of teeth which is the main cause of nutrient alteration causes difficulty in chewing some food, meat, fruit and vegetable. If edentulous is not replaced immediately, general health will be disturbed. In general the loss of teeth could affect the way of speaking, because the absence of teeth will make it difficult to pronounce words. ${ }^{3}$ Besides that Acharya ${ }^{4}$ and Franks (as cited in Zarb ${ }^{5}$ ) said that damage of temporomandibular joint (TMJ) is related with loss of teeth which further accelerates resorbtion of alveolar ridge. ${ }^{6}$

As the effects of extraction without replacement can be risky, the edentulous must be replaced with denture.
However, clinically, the edentulous space is neglected without treatment. There are some cases that make people do not replace their teeth, one of them is people's thinking pattern. Some say that the loss of only one tooth especially with no inconvenienced, does not need denture.

Many things can affect people's thinking pattern, attitude and behavior like income, experience, ideals, and sociocultural factors including norms and standards in family, community and especially education. Education is the changing process of attitude and behavior of a man or people to establish their maturity via study, training, and ways of educating. ${ }^{7}$ The higher the education, the higher the awareness and knowledge about dental treatment. Thus, prevalence of dental diseases like periodontal diseases, which are the main cause of teeth loss, can be minimized. ${ }^{8}$

Based on the above explanation, it is necessary to find out the thinking pattern of students of Faculty of Dentistry Hasanuddin University, especially the 2005 batch, as a part of community, as these freshmen are still early in their comprehension about dental hygiene.

This article aims to give description about thinking pattern of first grade student of Faculty of Dentistry Hasanuddin University towards edentulous replacement.

\section{MATERIALS AND METHODS}

This descriptive study was conducted to all first year students of Faculty of Dentistry Hasanuddin University. Data was collected at the Lecture Room on the December 2005. 
Sampling was based on purposive sampling technique. ${ }^{9}$ Criterion of the sample is to have at least one edentulous tooth. Based on that criterion from 102 participants, 30 students were determined to be the sample of this study. The answers given are expected to inform the thinking pattern of the students towards edentulous replacement. Because some respondents gave contradictory answers, interview was carried out to students. Examination and interview were carried out to 30 students who stated edentulous in their questionnaire.

In this study, edentulous is defined as the loss of teeth, at least one tooth, caused by periodontal diseases, caries, orthodontic treatment, and trauma. In other words, edentulous is a state without natural teeth in mouth. ${ }^{10}$ Definition of thinking pattern in this study is student's comprehension towards edentulous replacement. Thinking pattern is comprehension of people to solve a problem. ${ }^{11}$

Data which was descriptively analyzed by systematically explain the results of the study and then distributed data in tables.

\section{RESULTS}

This study shows the non-edentulous 72 students consisted of 18 males and 54 females and the 30 edentulous students having consisted of 3 males and 27 females, as can be seen from table 1 which shows respondents' identity.

Table 2 shows the answers of some questions. All the answers to the question "Have you replaced the edentulous with denture," are "not use denture." From the question "Is there any family using denture," 26 sample of edentulous and 50 of non-edentulous answer "having family using denture with various types of family relationship."
Table 1. Respondents' identity

\begin{tabular}{|c|c|c|c|c|}
\hline \multirow{2}{*}{ No } & \multirow{2}{*}{ Identity } & \multicolumn{2}{|c|}{ Students } & \multirow{2}{*}{ Total (students) } \\
\hline & & $\mathrm{E}$ & WE & \\
\hline \multirow[t]{3}{*}{1} & Gender & & & \\
\hline & - male $\left(\sigma^{\pi}\right)$ & 3 & 18 & 21 \\
\hline & - female (ㅇ) & 27 & 54 & 81 \\
\hline \multirow[t]{5}{*}{2} & Age (year) & & & \\
\hline & -17 & 4 & 7 & 11 \\
\hline & -18 & 13 & 46 & 59 \\
\hline & -19 & 11 & 16 & 27 \\
\hline & -20 & 2 & 3 & 5 \\
\hline \multirow[t]{6}{*}{3} & Parents occupation & & & \\
\hline & - civil servants & 20 & 49 & 69 \\
\hline & - entrepreneur & 10 & 14 & 24 \\
\hline & - official & - & 4 & 4 \\
\hline & - retired & - & 3 & 3 \\
\hline & - miscellany & - & 2 & 2 \\
\hline
\end{tabular}

Note: E: Edentulous; WE: Without Edentulous

Regarding the question "If your teeth are extracted, will you use dentures?" 23 edentulous and non-edentulous 69 people respectively "yes." For the question "In your opinion, caries is better treated or extracted," 57 students answered "caries need to be treated."

Table 3 shows that $96.67 \%$ edentulous students said it is necessary to replace edentulous with denture and $3.33 \%$ considered unnecessary. While $98.61 \%$ of the nonedentulous students answered it is necessary.

Table 4 showed that for the edentulous group aesthetic reasons $(56.67 \%)$ are the main factor to consider in using denture while both aesthetic and chewing $(20 \%)$ seem to be the second important factor. While the non-edentulous students need to use denture due to aesthetic and chewing reasons $(43.06 \%)$ and aesthetic reason only $(22.22 \%)$.

Table 2. Distribution of answers of the edentulous people

\begin{tabular}{|c|c|c|c|c|c|c|c|c|c|c|c|c|c|c|c|}
\hline \multirow{3}{*}{ No } & \multirow{3}{*}{ Question } & \multicolumn{3}{|c|}{ Answer } & \multicolumn{4}{|c|}{ Answer } & \multicolumn{4}{|c|}{ Answer } & \multicolumn{3}{|c|}{ Answer } \\
\hline & & \multirow[t]{2}{*}{$\mathrm{Y}$} & \multirow[t]{2}{*}{$\mathrm{N}$} & \multirow[t]{2}{*}{ Ev } & \multicolumn{2}{|c|}{ Ed } & \multicolumn{2}{|c|}{ WEd } & \multicolumn{2}{|c|}{ Ed } & \multicolumn{2}{|c|}{ WEd } & \multirow[b]{2}{*}{$\mathrm{T}$} & \multirow[b]{2}{*}{ Ex } & \multirow[b]{2}{*}{$\mathrm{DC}$} \\
\hline & & & & & $\mathrm{Y}$ & $\mathrm{N}$ & $\mathrm{Y}$ & $\mathrm{N}$ & $\mathrm{Y}$ & $\mathrm{N}$ & $\mathrm{Y}$ & $\mathrm{N}$ & & & \\
\hline 1 & $\begin{array}{l}\text { Have you replaced your } \\
\text { edentulous with denture }\end{array}$ & - & 30 & - & & & & & & & & & & & \\
\hline 2 & Has any your family used & & & & 26 & 4 & 50 & 22 & & & & & & & \\
\hline & denture?: & & & & 6 & & 9 & & & & & & & & \\
\hline & - Father & & & & 5 & & 7 & & & & & & & & \\
\hline & - Mother & & & & 4 & & 5 & & & & & & & & \\
\hline & - Grandfather & & & & 14 & & 25 & & & & & & & & \\
\hline & - Grandmother & & & & 3 & & 6 & & & & & & & & \\
\hline & - Uncle & & & & 2 & & 13 & & & & & & & & \\
\hline & - Aunt & & & & 1 & & 2 & & & & & & & & \\
\hline & - Cousin & & & & 1 & & - & & & & & & & & \\
\hline 3 & $\begin{array}{l}\text { - Sibling } \\
\text { If your teeth are extracted, } \\
\text { will you use dentures }\end{array}$ & & & & & & & & 23 & 7 & 69 & 3 & & & \\
\hline 4 & $\begin{array}{l}\text { In your opinion, caries is } \\
\text { better treated or extracted }\end{array}$ & & & & & & & & & & & & 57 & 4 & 41 \\
\hline
\end{tabular}

Note: Y: Yes; N: No; Ev: Ever; T: Treated; Ex: Extracted; DC: Depending on the case; Ed: Edentulous; WEd: Without edentulous. On question no. 2: there were some students answered more than one family relation. 
Table 3. Distribution of answers to the question "Is it necessary to replace edentulous with denture?"

\begin{tabular}{|c|c|c|c|c|c|c|c|c|}
\hline \multirow{3}{*}{ Question } & \multicolumn{4}{|c|}{ Edentulous } & \multicolumn{4}{|c|}{ Without edentulous } \\
\hline & \multicolumn{4}{|c|}{ Number of students } & \multicolumn{4}{|c|}{ Number of students } \\
\hline & & Necessary & & hecessary & & Necessary & & necessary \\
\hline $\begin{array}{l}\text { Is it necessary to replace } \\
\text { edentulous with denture? }\end{array}$ & 29 & $96.67 \%$ & 1 & $3.33 \%$ & 71 & $98.61 \%$ & 1 & $1.39 \%$ \\
\hline
\end{tabular}

Table 4. Distribution of reasons to use denture

\begin{tabular}{|c|c|c|c|c|c|}
\hline \multirow{2}{*}{ No } & \multirow[b]{2}{*}{ Reasons to use denture } & \multicolumn{2}{|c|}{ Edentulous } & \multicolumn{2}{|c|}{ Without edentulous } \\
\hline & & Total & $\%$ & Total & $\%$ \\
\hline 1 & Aesthetic & 17 & 56.67 & 16 & 22.22 \\
\hline 2 & Chewing & 1 & 3.33 & 9 & 12.50 \\
\hline 3 & Phonetic & - & - & - & - \\
\hline 4 & Aesthetic and chewing & 6 & 20.00 & 31 & 43.06 \\
\hline 5 & Aesthetic and phonetic & 1 & 3.33 & - & - \\
\hline 6 & Phonetic and chewing & 1 & 3.33 & 1 & 1.39 \\
\hline \multirow[t]{2}{*}{7} & Chewing, aesthetic and phonetic & 4 & 13.34 & 15 & 20.83 \\
\hline & Total & 30 & 100 & 72 & 100 \\
\hline
\end{tabular}

Table 5. Distribution of reasons not to use denture

\begin{tabular}{clc}
\hline No & \multicolumn{1}{c}{ Reasons } & Total \\
\hline 1 & Do not have sufficient time & 12 \\
2 & Do not feel disturb & 7 \\
3 & Expensive & 5 \\
4 & Do not care about it & 3 \\
5 & Afraid & 1 \\
6 & Do not yet think about it & 2 \\
7 & Orthodontic & 6 \\
\hline & $\quad$ Total & 36 \\
\hline
\end{tabular}

Note: Some students answered more than one reason.

Table 5 showed factors that make edentulous students not use denture; first, do not have sufficient time to see dentist (12 students), do not feel disturb (7 students), and high cost (5 students). There was 1 student who feels fear using denture because of hearing complaint and inconvenience from his family. Two students answered they do not care about using denture.

\section{DISCUSSION}

This study of thinking pattern of fresh students at faculty of dentistry Hasanuddin University towards edentulous replacement shows that females more often visiting dentists than males do (table 1). However, this finding indicates that their visits are generally for extraction. This is line with Stoll, ${ }^{1}$ who said that females more often visit to dentist than males do. This may be caused by the fact that men are not patient enough to observe their teeth. If caries or periodontal diseases exist, which are the main causes of tooth loss, ${ }^{12}$ they tend to be neglected. Moreover, from an observation, some roots are left at their position, so they can not be identified as edentulous.

Besides gender, age is another factor that affects someone to treat their teeth. Based on a finding cited in Stoll, ${ }^{1} 50 \%$ people who treated their teeth were younger than 45 years old, while only $26 \%$ people who are older than 65 years. In this study the effect of age to dental treatment has not been seen because the age of samples did not vary and the number of sample is very view (Table 1).

Condition of family also determines dental health of children and adolescent especially in making decision whether to use denture. Some families are of highereducation parents and others are not. ${ }^{13}$ Socio-economy condition of a family can be determined by their education, occupation, and income. Those factors affect each others. Occupation, for instance, can be affected by education grade, or family income that can be affected by occupation. ${ }^{9}$

Generally, there are some occupations which are covered by insurance subsidy; this affects someone in determining to look for best dental treatment appropriate with his finance. Payment planning made someone does not make a problem out of treatment payment. All of above, it is education grade, parents income that can be known from the occupation, or the type of health insurance subsidy from the occupation, affect the family in looking for health service. ${ }^{14}$

Origin town can affect someone to look for dental health service. There are areas that can be found dental health service easily (community health centre, hospital, and dentist), until the community can choose easily. On the other side, there are areas that have only a little even nothing dental health service, until complicate them to choose dental health service. In this study, majority of the respondents came from Makassar which has many dental health services. 
It can be hoped that this factor is not constitute a problem for someone gaining dental health service.

Table 2 showed answers of some questions. The majority answers of question "will you use denture if you have edentulous?" is "yes." This pointed that they have had comprehension towards the important using denture. But from question "have you replaced the edentulous with denture," all samples answered "no." If being observed from education that they are having, actually surprised, but this thing may be caused by they still have great effects from their family and environment, because they are still in the early grade. This point contradiction enough with data on table 3 that showed majority of respondents that have edentulous said "it's necessary replace edentulous because there are many negative effect of edentulous," for instance disturb chewing, ${ }^{3-5,15-17}$ aesthetic, ${ }^{4-6,15,18}$ and phonetic. ${ }^{3,15,18}$

Behavior has an important role in affecting dental health condition, because besides of affect dental health condition directly, behavior can affect environment factor and health service. ${ }^{19}$

Bloom that cited by Astoeti, ${ }^{19}$ said that behavior could be divided into 3 types, it is cognitive, affective, and psychomotor. Then Sears et al, ${ }^{20}$ said that cognitive consists of understanding of someone about something objects, it is fact, knowledge, and conviction about object. Affective consists of all feeling or emotion of someone to the object, mainly evaluation. While psychomotor consists of practice or action did by someone.

From the conditions above, can be seen that majority of respondents have known the important of replacing edentulous with denture; the cognitive component plays. Now, they think that replace edentulous is very useful and can avoid from negative effect of tooth loss; affective component plays. Furthermore, "will they use denture?" From this study, there was no student used denture. With other words, like said by Sears et al, ${ }^{20}$ that psychomotor component does not always similar with cognitive and affective. The unconformity between behavior components may be caused by some matters which considered why they do not replace their edentulous.

Sears et al. ${ }^{20}$ said that behavior of someone affected by their knowledge or comprehension, but generally behavior mainly affected by all evaluation of those people, positively or negatively. A man always acts that based on the profit and the loss of behavior.

In this case, the respondents understood the important using denture and feel very useful, but the other side they think that for gaining that benefit, they must sacrifice many things. They feel the profit and the loss does not comparable, so the actions be done were the more profit and nothing loss.

Still from table 2, the question "is there any family using denture," majority respondents have family that using denture. People around respondents were very affecting them, to use denture or not. Since born, a child had contacted with people around him. First, with his family mainly father and mother, then brother and sister, uncle, aunt, etc. In children development, family role, mainly father and mother, is very important and determine the formation of their personality in the future. ${ }^{13}$

Table 3, which shows the necessity of edentulous replacement, shows that majority of edentulous and nonedentulous respondents, answered "necessary" with vary reasons that can be seen at table 4 . The main reasons are aesthetic and chewing factors. This matter similar Basker's statement that cited by Kusmawati, ${ }^{21}$ it is that main motivation of a patient using denture in the first time usually aesthetic and chewing factors. ${ }^{5}$ From this point, can said that aesthetic still be the main purpose of treatment, whereas generally tooth loss causes complaint in phonetic and chewing, too.

Although respondents on average answer "it is necessary to replace edentulous," but from students that having edentulous, in fact, shows there is no students using denture. The considerations of the students who did not use denture as can be seen at table 5 are as follows. First, there was no sufficient time to visit dental health service because they were busy, the health service centres were far from home, or they thought edentulous as unimportant. ${ }^{14}$ Second, they felt their daily activities were not disturbed by tooth loss even they had pain and inconvenience. The pain often neglected because they think it will leave immediately. Besides of that, there are people do self-treatment just to relief the pain. ${ }^{14}$ Third, the fee was very expensive. This factor is still form a constraint that can not be overcome by the community. Whereas many people can surpass that problem, but fee factor can not be neglected. Suppose to get health insurance subsidy, many people do not exploit it because its arrangement is difficult and its administration service is not satisfied. ${ }^{14,21}$ Fourth, they did not care, and they were lazy and indifferent. This matter is a personality problem that affected by environment or follows the family. Fifth, they felt fearful using denture after hearing complaint and inconvenience from denture user, then the feeling closes to children mind and develops greater if they does not gain a right and clear explanation. Sixth, the effect of edentulous was not felt yet. And the seventh, the space will close in the future after orthodontic treatment.

From this study, it can be concluded that majority respondents have known the important replacing edentulous. As dental students, 2005 batch have shown right comprehension towards edentulous replacement. Aesthetic still be the main factor in using denture. However, behavior in using denture has not been formed because it is affected by external and internal factors. External factors are family, time, economy, education, official attitude, and environment. Internal factors consist of knowledge, thinking pattern, and behavior. From those factors, time is the main external factor in using denture. While thinking pattern, that is internal factor, seen plays important role. Their evaluation about profit and loss in using denture will be the main reason using denture or not. 


\section{ACKNOWLEDGEMENT}

The author is indebted to Miss. Atri, who had participated in this study by helping collected data in questionnaire, interview, and oral examination.

\section{REFERENCES}

1. Stoll FA. Dental health education. $5^{\text {th }}$ ed. Philadelphia: Lea \& Febiger; 1977. p. 17-24.

2. McGuire. Tooth fitness your guide to healthy teeth. Nevada: St. Michaels's Press; 1994. p. 139.

3. University of Texas Health Science Center at San Antonio. Effects of tooth loss. 2001. Available from: URL: http://www.teachhealthk12.uthsca.edu/pa/pa09/pa09pdf/0906LSN.pdf. Accessed November 19, 2005.

4. Acharya V. Save your teeth. 2004 Jun. Available from: http://www. hindu.com/thehindu/mag/2004/06/20/stories/2004062000410600. htm. Accessed November 22, 2005.

5. Zarb GA, Bergman BO, Clayton JA, Mackay HF. Prosthodontic treatment for partially edentulous patients. Saint Louis: The CV Mosby Company; 1978. p. 26.

6. Merck \& Co. Inc. Mouth and dental disorders. 2005. Available from: http://www.merck.com/pubs/mmanual ha/sec3/ch39/ch39e.html. Accessed November 19, 2005

7. Budiharto. Perilaku kelompok masyarakat rendah di perkotaan terhadap kesehatan gigi tahun 1999. Jurnal Kedokteran Gigi Universitas Indonesia 2000; 7(2):40-1.

8. Carranza FA. Glickman's clinical peridontology. $9^{\text {th }}$ ed. London: WB Saunders Company; 2002. p. 90.
9. Notoadmodjo S. Metodologi penelitian kesehatan. Jakarta: PT Rineka Cipta; 2005. p. 68, 70, 88-9.

10. Harty FJ, Ogston R. Kamus kedokteran gigi. Sumawinata N, editor. Jakarta: EGC; 1995. p. 102.

11. Bono E. Lateral thinking. 2006. Available from: http://en.wikipedia org/wiki/Lateral thinking. Accessed February 5, 2006.

12. Odusanya SA. Tooth loss among Nigerians: causes and pattern of mortality. Int J Oral Maxillofac Surg 1987; 16 (2): 184-9. Available from: http://www.ncbi.nlm.nih.gov/entrez/query.fcgi?cmd=Retri eve $\& \mathrm{db}=$ Pubmed $\%$ list-uids $=10946463 \& \mathrm{dopt}=$ Citation. Accessed December 11, 2005.

13. Purwanto MN. Psikologi pendidikan. Bandung: PT Remaja Rosdakarya; 2002. p. 104, 158, 161.

14. Notoadmodjo S. Pendidikan dan perilaku kesehatan. Jakarta: PT Rineka Cipta; 2003. p. 10, 13, 121, 124-5, 179, 195-6, 202.

15. Gordon J. Missing teeth? Weigh your options. Available from:http:// www.dentalcomfortzone.com/archive/MissingTeeth.html. Accessed November 22, 2005.

16. Ferreira L. Teeth in a day. 2005. Available from http://www. dentalimplants-usa.com/Misc?newsrelease/NaturalHealthWeb/ naturalhealthweb.html. Accessed November 22, 2005.

17. Hutton B, Feine J, Morais J. Is there an association between edentulism and nutritional state?. J Can Dent Assoc 2002; 68(3):182-3.

18. Prajitno HR. Ilmu gigitiruan jembatan. Jakarta: EGC; 1991. p. 2.

19. Astoeti TE, Boesro S. Pengaruh tingkat pengetahuan terhadap kebersihan gigi dan mulut murid-murid SDN DKI Jakarta. Jurnal Kedokteran Gigi Universitas Sumatera Utara 2003; 2(8):149.

20. Sears DO, Freedman JL, Peplau LA. Psikologi sosial. Adryanto M, Soekrisno S, editors. Jakarta: Erlangga; 1994. p. 14, 138-41.

21. Azwar A. Pengantar administrasi kesehatan. $3^{\text {rd }}$ ed. Jakarta: Binarupa Aksara; 1996. p. 157-8. 